\title{
Um dândi nos trópicos: esporte e educação do corpo nas crônicas de Paulo Barreto (João do Rio)
}

\section{A dandy in the tropics: sport and body education in the chronicles of Paulo Barreto (João do Rio)}

\author{
André Mendes Capraro* \\ Marcelo Moraes e Silva*
}

\begin{abstract}
RESUMO
O presente artigo teve como objetivo analisar como o esporte e os processos de educação do corpo se manifestaram nas crônicas de Paulo Barreto, mais conhecido como João do Rio. As fontes selecionadas foram as crônicas publicadas pelo literato até 1921, ano de sua morte, cujo assunto primário ou secundário tenha sido o esporte. A palavra se mostrou presente na obra do escritor, porém se manifestou de uma forma ampla, ora repercutindo pontos positivos ora enfatizando aspectos negativos, mas como característica comum as diversas maneiras de educação do corpo. A título de conclusão, aponta-se que o esporte foi acionado pelo autor para representar as facetas existentes no seio da sociedade carioca e que nessas representações estavam evidentes modos de vida que possuíam alguns elementos educacionais relativos ao corpo.
\end{abstract}

Palavras-chave: Esporte. Educação do Corpo. Rio de Janeiro. João do Rio.

\section{ABSTRACT}

This article aimed to analyze how the chronicles of Paulo Barreto, better known as João do Rio, manifested sport and processes related to the education

* Universidade Federal do Paraná. Programa de Pós-Graduação em Educação Física. Curitiba, Paraná, Brasil. E-mail: andrecapraro@gmail.com - https://orcid.org/0000-0003-3496-3131 E-mail: marcelomoraes@ufpr.br - https://orcid.org/0000-0001-6640-7952 
of the body. The sources selected were the writer's chronicles published until 1921, the year of his death, and whose primary or secondary subject was sport. The word was broadly present in the author's work, sometimes reflecting positive points and sometimes emphasizing negative aspects, but always as a conventional feature of different ways of educating the body. In conclusion, the writer used the sport to represent the facets that existed within the society of Rio de Janeiro, and these representations evidence ways of life that had educational elements related to the body.

Keywords: Sport. Body Education. Rio de Janeiro. João do Rio.

\section{Introdução}

Não é de causar espanto que em plena belle époque brasileira - uma súbita e atabalhoada tentativa de aproximação com os ditos civilizados costumes europeus (SEVCENKO, 1998; MORENO, 1999; LUCENA, 2001) - algum literato tentasse se apresentar como o paladino do dandismo no Brasil ${ }^{1}$ (LEVIN, 1996; CAPUANO, 1999). Este escritor foi Paulo Barreto, o João do Rio, um indivíduo ligado ao cotidiano da sua cidade natal, o Rio de Janeiro. Uma ambiência, ao menos a dos segmentos populacionais mais abastados, efervescente: a luz e os bondes elétricos, os jardins e os parques ao estilo francês, o chá das 5 horas em confeitarias (como a renomada Colombo), os saraus e bailes, o fluxo para assistir eventos de turfe, remo, futebol, entre outros esportes, os automóveis, os belos e jovens corpos... Nada passou despercebido ao olhar de João do Rio. Sevcenko (1998, p. 568-569) apresenta tal cenário com precisão cirúrgica:

Essa expressão "civilização esportiva" [Termo designado em uma crônica de Machado de Assis, criticando a juventude de sua época], portanto não deve ser entendida como se referindo exclusivamente à prática generalizada de diferentes esportes, mas a generalização de uma ética do ativismo, a ideia de que é na ação e portanto no engajamento corporal que se concentra a mais plena realização do destino humano. As filosofias da

1 Doutrina, movimento, cultura ou estilo de vida, originário na Europa, que consistia na supervalorização da estética, principalmente no campo artístico. Na literatura a introspecção cede lugar à superficialidade, isto é, apenas à aparência. O belo serve então de valor moral, ideológico e ético. A estética é a referência para vida. A aparência é transformada em essência. Desta forma, podese concluir que um dândi estava perfeitamente ambientado com a frivolidade típica da belle époque. 
ação, os homens de ação, as doutrinas militantes, os atos de arrebatamento e bravura tornam os índices nos quais as pessoas passam a se inspirar e pelos quais passam a se guiar. É o tremedal de que falava João do Rio.

Essa ética do ativismo levantada por Sevcenko (1998) atribuía um importante papel ao esporte nos processos de educação do corpo dos habitantes da então capital federal. A novidade vinda do continente europeu era símbolo de hábitos e costumes considerados civilizados e por este motivo deveria ser difundida na cidade do Rio de Janeiro. Sendo assim, conforme sugere Lucena (2001), não é de se estranhar que diversos cronistas utilizassem das páginas dos periódicos cariocas com o intuito de valorizar o esporte e toda a educação do corpo nele embutida.

As crônicas, ao tratarem de temas mundanos, como as práticas esportivas, acabaram se tornando uma importante ferramenta educacional, visto que, conforme apontou Sevcenko (1983), existia por parte dos literatos brasileiros do período um sentimento de "missão civilizacional". A imprensa se legitimava como um espaço de idealização de imagens, contribuindo na formação de uma comunidade imaginada, conforme sugere Anderson (2008). Consequentemente, esse movimento acabou acionando diversos mecanismos educacionais que afetaram os corpos dos indivíduos, prescrevendo, interditando e ditando modos de vida. Nesse sentido, pode-se afirmar que as crônicas escritas por literatos, como as de João do Rio, tornaram-se também difusoras de uma educação do corpo na virada do século XIX para o XX.

Cabe destacar que se entende por educação do corpo aquilo que Soares (2014) indica como uma progressiva repressão de manifestações corporais que pareciam ser incontroláveis. Para a autora, educar o corpo é torná-lo adequado ao convívio social, bem como inseri-lo em processos de aprendizagens que buscam apagar uma natureza rebelde, trazendo à luz uma natureza pacificada. Essa noção permite escrever uma história da educação, ou talvez, nas palavras de Soares (2003), uma história dos múltiplos constrangimentos, pois é no corpo que se inscreve um lento, intenso, extenso, meticuloso e obstinado trabalho de constrangimentos. A autora salienta que para ser exibido o corpo precisa ser educado e as ações pedagógicas percorrem múltiplos caminhos, elaborando práticas ambíguas e tensas. Nesse contexto, as práticas esportivas manifestas nas crônicas dos diversos escritores, como Coelho Neto, Gilberto Amado, Lima Barreto, Machado de Assis, Olavo Bilac e Paulo Barreto, também estavam marcadas, cada um à sua maneira, por esta educação do corpo, pois nas suas entrelinhas figuravam elementos de uma "missão civilizacional". 
Nesse sentido, o presente artigo tem como objetivo analisar a produção textual de João do Rio acerca do esporte e da perspectiva de educação do corpo, com ênfase no gênero crônica. Para tanto, foram usados os preceitos básicos da análise literária (MICELI, 1977; CANDIDO, 2000; ECO, 2003), com ênfase no trato específico ao gênero crônica, como preconizado por Candido (1992). A teoria de Candido, portanto, serve como um contraponto ao dualismo acadêmico entre autonomia artística versus reflexo social. Com uma abordagem próxima à sociologia literária, Candido (2000, p. 4) propõe a utilização da literatura como um instrumento de conhecimento crítico:

Hoje sabemos que a integridade da obra não permite adotar nenhuma dessas visões dissociadas; é que só a podemos entender fundindo texto e contexto numa interpretação dialeticamente íntegra, em que tanto o velho ponto de vista que explicava pelos fatores externos, quanto o outro, norteado pela convicção de que a estrutura é virtualmente independente, se combinavam como momentos necessários do processo interpretativo. Sabemos, ainda, que o externo (no caso, o social) importa, não como causa, nem como significado, mas como elemento que desempenha um certo papel na constituição da estrutura, tornando-se, portanto, interno.

O diagnóstico deste fator interno se dá por meio do entendimento do conjunto da produção: as temáticas mais abordadas, a forma de entendimento do tema, a facilidade - ou não - para mudar de opinião, enfim, a personalidade literária de um escritor. Assim, de acordo com os postulados de Candido, trata-se de uma interpretação profunda da estética que acabou incorporando a 'dimensão social' como conteúdo da obra. Quando se chega neste nível de compreensão "[...] o externo se torna interno e a crítica deixa de ser sociológica para ser apenas crítica" (CANDIDO, 2000, p. 7).

Ao selecionar a produção literária de João do Rio, com ênfase no gênero crônica, teve-se em conta o amplo alcance social dos seus textos. Sem dúvida, o autor se tornou nas primeiras décadas do século XX um dos mais consagrados cronistas brasileiros (LEVIN, 1996; O'DONNELL, 2008). Acredita-se, desta forma, na relevância das suas contribuições para a produção de ideias acerca da relação entre corpo/esporte/educação. Consequentemente, partiu-se da premissa de que se João do Rio fosse uma referência na literatura brasileira, um reconhecido formador de opinião, também seria significativa a repercussão dos seus escritos na sociedade. Como clássico nacional, os textos de João do Rio foram publicados por várias editoras, em seguidas edições. Suas crônicas, 
originalmente exibidas em periódicos, foram coletaneadas e editadas no formato de livros. Algumas, inclusive, já passaram ao domínio público, sendo publicadas em várias coleções. Os escritos aqui analisados foram obtidos neste tipo de obra, as coletâneas.

\section{Paulo Barreto, o João do Rio: uma breve biografia}

João Paulo Emílio Cristóvão dos Santos Coelho Barreto era mais conhecido pelo simplificado Paulo Barreto e, já famoso, por alguns pseudônimos literários, como Caran d'ache, Joe, José Antônio, José ou ainda João do Rio - epíteto pelo qual seria mais reconhecido até do que pelo próprio nome (CAMILOTTI, 2004). Nascido em 1881 e filho de um professor, quando menino foi educado segundo o ideário positivista, já que seu pai era um seguidor convicto da obra de Auguste Comte. Mesmo com o estímulo paterno, Paulo Barreto não manifestou interesse na doutrina. Precocemente, mesmo para os padrões da época, tornou-se jornalista (aos dezesseis anos de idade), trabalhando em vários periódicos cariocas. Posteriormente, foi considerado o precursor do jornalismo moderno no país (LEVIN, 1996; GOMES, 1996; RODRIGUES, 1996; O’DONNELL, 2008).

Paulo Barreto foi um dos primeiros a destacar a importância da urgência na reportagem, ou seja, responsável pela criação do termo técnico "furo de reportagem". Também foi buscar em outras áreas, como a Sociologia, a Antropologia e a História (principalmente helênica), subsídios para sua produção jornalística (RAMOS, 1990). Ainda nos jornais acentuou o uso da entrevista como recurso de informação. Enfim, no meio jornalístico foi um inovador (LEVIN, 1996; GOMES, 1996; O’DONNELL, 2008).

Preocupado com o cotidiano da cidade, o autor usava da sua forte percepção dos fenômenos sociais para tratar de temas que despertavam a atenção do público leitor, desta forma, cativando-o e criando uma relação de fidelidade. Foi considerado por muitos como o primeiro cronista moderno, pois abandou o estilo folhetinesco para lançar a crônica diária, descompromissada, com uma razoável dose de humor e deboche, além de inserir os personagens do dia a dia carioca (VENEU, 1990; LEVAN, 1996; GOMES, 1996).

Era notório que Paulo Barreto tinha uma forte identificação com a sua cidade natal (VENEU, 1990; O'DONNELL, 2008). Em virtude deste enlace com a urbe, foi um dos primeiros literatos a fortalecer o aspecto social da crônica (LEVIN, 1996). Neste contexto, foi inevitável que os esportes - principalmente o futebol - ainda galgando espaço na sociedade brasileira, logo chamassem a 
sua atenção. Neste momento, em 1916, sua opinião anteciparia a de Gilberto Amado: o esporte (representado pelo futebol) era um assunto digno de nota: "Não! Há de fato uma coisa séria para o carioca: o foot-ball! Tenho assistido a meetings colossais em diversos países, [...] nessas grandes festas de saúde, de força e de ar. Mas absolutamente nunca eu vi o fogo, o entusiasmo, a ebriez da multidão assim" (JOÃO DO RIO, 1916 apud RAMOS, 1990, p. 20).

Porém, Paulo Barreto era um cronista e uma característica da crônica, como apontam alguns especialistas no gênero é exatamente o exasperar de opiniões diversas (CANDIDO, 1992). Faz sentido, pois a crônica é presa aos fatos mundanos (triviais ou não) do cotidiano e estes se alteram regularmente (ARNT, 2001). Logo, João do Rio não se preocupava muito em manter um ponto de vista. Por exemplo, no romance "A Profissão de Jacques Pedreira", publicado originalmente em 1911, o futebol apareceu de forma estereotipada, por meio daquele típico dualismo estabelecido pela intelectualidade do início do século XX: de um lado o esporte e do outro a educação, sendo considerados incompatíveis. O conflito é demonstrado neste excerto que foca na relação de um jogador de futebol com um professor de filosofia:

Os preparatórios deixaram-lhe uma sensação de igualdade inexplicável e que no fundo sempre lhe pareceu desagradável rebaixamento. Havia uma porção de rapazes de má roupa, sem vergonha pobres, e que se permitiam, entretanto, fazer versos, usar pince-nez e não lhe ligar a menor importância. Quando os professores falavam - (de modo geral sempre) - da desmoralização do ensino, da inferioridade da geração, esses rapazes tinham a impertinência de olhá-lo e ele não podia deixar de ficar contrariado, porque esses sujeitinhos é que lhe pareciam inferiores. Os últimos tempos passara-os mesmo a jogar football, jogo em moda que as senhorinhas aclamavam aos domingos em Paissandu. Foi sob essa brilhante vocação esportiva, que se matriculou para fazer o primeiro ano. O primeiro ano constava de duas matérias: Filosofia de Direito e Direito Romano. Oito dias antes dos exames, começou de ler umas apostilhas da segunda matéria, veneráveis apostilhas que representavam o saber desse monumento social em dez gerações de bacharéis. Em Filosofia copiou a prova escrita e na oral, diante de um lente grosso e sábio, assegurou:

- A Filosofia, esse verdadeiro pão do espírito...

O professor abriu numa gargalhada homérica. E ainda sacolejado de riso: - Continue, muito bem... continue, menino... (BARRETO, 2002a, p. 14). 
O literato não se dedicou somente à crônica, escreveu também vários ensaios sobre crítica literária, peças teatrais, novelas, contos e até um romance, além da tradução de várias obras de destaque da literatura mundial, como os romances de Oscar Wilde. Devido a sua reconhecida produção (e uma intensa campanha) foi indicado a uma cadeira da Academia Brasileira de Letras, a pertencente a Guimarães Passos, isto antes de completar trinta anos de idade fato notório para um literato (VENEU, 1990; GOMES, 1996; RODRIGUES, 1996; O’DONNELL, 2008).

Mesmo publicando obras de gêneros diferenciados, Paulo Barreto jamais abandonou os periódicos. Iniciou no Cidade do Rio, sendo fundador do Rio Jornal, A Pátria e a Revista Atlântica todos na década de 1910. Também foi o criador da Sociedade Brasileira de Autores Teatrais, espaço onde teve contato direto com várias personalidades da intelectualidade nacional, inclusive de outros tipos de arte que não a literária (GOMES, 1996; LEVAN, 1996).

O escritor morreu jovem, antes de completar a quarta década de vida, em 1921. Mesmo assim, deixou uma vasta produção, principalmente de crônicas. Sua popularidade era tão grande que seu corpo teve que ser velado (com exposição pública) na própria redação de $A$ Pátria. No dia seguinte, o féretro agregou mais de cem mil populares (GOMES, 1996; RODRIGUES, 1996; O'DONNELL, 2008). Em uma época em que os escritores tinham que fazer um esforço sobrehumano para sobreviver - já que a grande maioria da população não conseguia sequer assinar o próprio nome, quanto mais ler uma obra literária - Paulo Barreto já tinha um status de celebridade. Como é dado a entender por um diário carioca no dia seguinte ao de sua morte:

O passamento de Paulo Barreto, occorrido hontem á noite, foi uma surpreza que impressionou profundamente o meio espiritual, as camadas litteraria e jornalistica, prolongando-se essa impressão a todas as rodas sociaes, onde essa individualidade, que o era, tinha um realce de admiração e de estima. E esse destaque bem frisante surge evidenciado, precisamente pela unanimidade das revelações de pezar ante o desapparecimento do litterato, do jornalista e do homem, mórmente deste, que não podendo escapar á fragilidade da perfeição humana, se tinha defeitos, bem os recompensava com o seu nucleo de virtudes. [...] Mas a sua feição saliente nas letras era o jornalismo, a sua espiritualidade pendia muito mais, e com relevo de valor, na columna do jornal, do que na pagina do livro; naquella elle era o jornalista completo, tudo fazendo com a mais cabal proficiencia, não lhe escapando a minima 'ficelle' do mais simples facto tirando o preciso para o salientar, vibrar a pequena nota ou espiritualizar um "suelto", encher uma columna de chronica com actualidade de 
comentario e 'verve' de narrativa. A sua primeira prova de jornalista elle a deu, cabal, na celebre reportagem sobre as differentes religiões no Rio, que valeram á "Gazeta de Notícias" um bom renascimento de popularidade (WEGUELIN, [20--]) $)^{2}$.

O falecimento prematuro de João do Rio só serviu para acentuar sua condição de o cronista carioca mais popular até então. Ele tornou-se uma espécie de hour concour da literatura brasileira do início do século $\mathrm{XX}$, pois como, consequentemente, houve o encerramento da sua produção, o mercado editorial passou a se interessar pela publicação das crônicas do literato na forma de coletânea, fato pouco usual naquela época.

Como explicitado por Candido (1992), a crônica nasceu vinculada ao jornal, sendo assim, fadada a virar papel de embrulho. Paulo Barreto foi um dos primeiros escritores a quebrar tal máxima. De forma paradoxal, o trágico destino que o levaria à morte ainda jovem, em contrapartida, foi também o responsável por imortalizá-lo, já que foi um dos primeiros literatos dedicados primordialmente ao gênero crônica a ser publicado no formato de livro - este sim, surgido com uma característica de preservação sensivelmente maior do que a dos jornais e das revistas, conforme salienta Capraro (2013).

\section{Os múltiplos sentidos da palavra sport nas crônicas de João do Rio}

Se pensado o volume de crônicas publicadas por Paulo Barreto, o esporte poderia ser considerado um elemento não tão relevante para o autor como se supõem. As práticas esportivas não apareciam com uma regularidade que permitisse acreditar que o literato realmente estivesse envolvido com tal universo. Outros literatos da época (ou próximos a ela), como Lima Barreto, Coelho Netto e Machado de Assis se debruçaram sobre o tema com mais frequência. Se os poucos escritos de João do Rio sobre o esporte foram supervalorizados, isto se dá porque seu alcance era elevado em se tratando do público leitor de 
jornais ${ }^{3}$; e, secundariamente, porque após a morte as suas crônicas passaram a ser consideradas como textos com certo tom profético.

Torna-se perceptível a forte coesão de Paulo Barreto com o seu leitor. É sensível também o seu poder de persuasão e argumento e consequentemente, ampla aceitação dos seus textos, evidenciando assim também uma perspectiva educacional. Assim, mesmo com a pequena quantidade de crônicas publicadas acerca do esporte, não há como negar a relevância do conteúdo e seu inconteste impacto (ao menos no Rio de Janeiro). Em síntese, o esporte era apresentado com foco na sua essência estética (com ênfase na elegância dos jovens atletas e na plástica dos movimentos), com pouco inovação interpretativa. Era a reprodução de um discurso típico dos admiradores do esporte, só que apresentado esteticamente de forma branda, evitando notoriamente o confronto com os radicais contrários à prática de atividades esportivas.

Em relação aos esportes, Paulo Barreto aparentava ter uma identificação e conhecimento esportivo maior sobre o remo. Nas primeiras décadas do século $\mathrm{XX}$, o remo era, de longe, um dos mais conhecidos esportes dentre aqueles praticados no Brasil (LUCENA, 2001; MELO, 2001).

E o Clube de Regatas do Flamengo foi o nucleo de onde irradiou a avassaladora paixão pelos sports. O Flamengo era o parapeito sobre o mar. [...] Então, de repente, veio outro club, depois outro, mais outro, enfim, uma porção. O Boqueirão, a Misericórdia, Botafogo, Icaraí, estavam cheios de centros de regatas (JOÃO DO RIO, 1916 apud RAMOS, 1990, p. 18).

Quanto ao futebol, o autor basicamente demonstrava certa surpresa com a dimensão que a atividade vinha ganhando nas primeiras décadas do século $\mathrm{XX}$ : "O campo do Flamengo é enorme. Da arquibancada eu via o outro lado, o das gerais, apinhado de gente, a gritar, a mover-se, a sacudir os chapéus" (JOÃO DO RIO, 1916 apud RAMOS, 1990, p. 20). O cronista não ia muito além disso, no máximo tentava buscar uma articulação com o colunismo social, destacando nomes de vulto da sociedade carioca presentes nos eventos futebolísticos que frequentava.

3 Paulo Barreto era o articulista mais popular na sua época, entretanto não poderia ser considerado o literato mais conhecido, pois, em se tratando de literatura em geral, conforme aponta Gonçalves (2016), os romances de Coelho Netto eram os mais lidos durante o período. 
Eu procurava conhecidos, estava todo o Rio e reconheci apenas a Sra. Nair Teixeira, com um delicioso vestido e Gastão Teixeira, que fazia gestos entusiásticos; a Sra. e as Senhorinhas Manoel Bernardes, a Senhorinha Carlo Vieira Souto, a Sra. e a Senhorinha Hime, as Senhorinhas Beatriz Tasso Fragosso e Maria Lima Campos e Regina Trindade, a Sra. João Felipe e as Senhorinhas Lanssance Cunha, Mariz, e Barros, Ivany Gonçalves, Maria Pinheiro Guimarães, Souza Leão, Pereira da Silva, Aracy Moniz Freire, Souza Alves, Ritinha Candiota, Otto Shilling, Maria Augusta Airosa, Hilda Kopeck, Dora Soares, Sofia Tavares de Lyra, Rocha Fragoso, Mibielli, Bento Borges (JOÃO DO RIO, 1916 apud RAMOS, 1990, p. 20).

A relação com o cotidiano, em determinadas situações, dá um toque de futilidade à crônica, já que sua proximidade com o colunismo - ambos pertencentes ao círculo de produção jornalística - é inegável. A estética adotada pelo autor torna a análise da sua produção bastante subjetiva. Se para alguns (CHALHOUB; PEREIRA, 1998; MELO, 2001) seus textos refletiam uma aceitação positiva do esporte, outros como Sevcenko (1998) acreditam que, por mais que João do Rio simpatizasse com os esportes, existiam em seus escritos um refinado deboche, uma sutil ironia à excessiva valorização que a sociedade carioca dava às atividades atléticas.

As duas possibilidades são contempladas nos subjetivos textos do literato, pois Paulo Barreto, se não fosse um legítimo dândi, simpatizava bastante com o movimento. Como descreve Capuano (1999), o personagem barão André de Belfort, um velho dândi, no romance "Dentro da Noite", publicado em 1910, era um "autorretrato" criado propositalmente pelo autor para demonstrar sua personalidade ao leitor. Como dito anteriormente, Paulo Barreto não era um apaixonado pelo esporte como outros literatos da sua época. Por sinal, em geral tinha uma opinião bastante oscilante. Volta e meia esnobava o modo de vida das elites republicanas, entretanto gostava muito de ir aos locais públicos (como os campos de futebol), mais interessado no fluxo de pessoas do que propriamente no jogo. Consequentemente, o barão Belfort, seu personagem alter ego, também o era:

Estávamos a almoçar cinco ou seis, convidados pelo barão Belfort, esse velho dandy sempre impecável, que dizia as coisas mais horrendas com uma perfeita distinção. E fora decerto uma extravagância aquele demorado almoço, a fazer horas para um match de foot-ball, a que seria impossível deixar de assistir. O barão, de veia, com a sua voz de navalha, recortava 
na pele dos presentes as caricaturas perversas. Nós já tínhamos rido muito e entrávamos com apetite num vulgaríssimo salmis 65 de coelho [...] (BARRETO, 2000, p. 27).

A adesão à cultura dândi ${ }^{4}$ por parte de Paulo Barreto se deu muito em virtude da tradução das obras de Oscar Wilde, um dos maiores representantes deste movimento estético/filosófico/literário. A obra que celebrou Wilde, " $O$ Retrato de Dorian Gray", publicada em 1890, tinha como protagonista um homem aristocrático com uma obsessão pela beleza e juventude, ao mesmo tempo em que se manifestava questionador dos ditames sociais da Era Vitoriana (WILDE, 2001). Dorian Gray (o personagem), assim como o próprio Wilde e escritores como Baudelaire, Lord Byron e Brummel (o suposto precursor), eram devotos da vida dedica à aparência estética, ao excepcional e, principalmente, ao ócio - logo, eram dândis $(E C O, 2004)$. A vida é literalmente transformada em arte transgressora. A maioria destes escritores eram exploradores da sexualidade; as experiências homoeróticas faziam parte da transgressão, mesmo que isto custasse um preço altíssimo, como no caso de Oscar Wilde.

Esta preocupação com a estética e principalmente com a forma textual, o retorno a um estilo de vida assumidamente guiado pela aparência estética (mesmo que crítico em relação ao modo de vida aristocrata) e a tendência a buscar a singularidade (no esforço de acentuar as diferenças entre os seres humanos) são as características mais típicas da cultura dândi presentes na produção literária de Paulo Barreto (CAMILOTTI, 2004). Vigarello e Holt (2008), indicam que o dândi - fosse o que fosse - valorizava uma educação estética que evidenciava uma inédita forma de postura. O dândi substituía os valores de classe da aristocracia por um novo valor corporal. Segundo os autores esse movimento possibilitou a emergência de um culto de si que produziu investimentos nas posturas físicas. A essência dândi consistia nesse gesto muito contemporâneo de entregar o indivíduo apenas às exigências de sua afirmação pessoal, ou seja, às qualidades de aparência corporal e, consequentemente, ao processo de educação do corpo.

Assim, torna-se mais compreensível o seu posicionamento oscilante a respeito do esporte e do seu valor educacional. Afinal, a diferenciação era um dos princípios da cultura dândi - enquanto ser humano uno, o indivíduo não

4 Existe uma polêmica se o dandismo poderia ser considerado uma cultura. Alguns críticos e acadêmicos defendem que seria um movimento literário e outros ainda um modo de vida. É uma questão ainda não fechada, sendo assim, adotou-se aqui a ideia de não os distinguir. 
deveria seguir padrões pré-determinados, tampouco convenções sociais. Era muito comum outrossim que, simpatizante do dandismo, João do Rio tendesse a ser "do contra", justificando, desta forma, seu caráter diferenciado. "Eu já estava um pouco fatigado dos matchs de football, dos law-tennis familiares, da ardente pelota basca, de toda essa diversidade de jogos a que se entrega o cidadão civilizado para mostrar que vive e se diverte. A briga de gallos seria um aspecto novo [...]" (BARRETO, 1909, p. 103).

Talvez, por isso, quando o esporte mal havia chegado ao país e a população o observava com desconfiança, o escritor demonstrasse em suas crônicas ser um simpatizante convicto da prática. Por outro lado, nos textos publicados posteriormente, as práticas esportivas já davam sinais de serem entediantes. Paulo Barreto passou, então, a propositalmente satirizar o ativismo à cultura atlética e à educação corporal advogada por esse discurso. Nesta fase, o termo esporte era usado de forma mais livre. A estratégia era usá-lo de modo variado e indevido, sempre evidenciando algum estilo de vida: "- O que dá forte acaba logo. Antes do circuito o club fecha, e então só resta apelar para a navegação aérea. Só há um sport que ainda não nos cansou: o falar mal da vida alheia..." (BARRETO, 2002a, p. 91).

Outros exemplos, estruturados de acordo com o significado simbólico dado ao esporte pelo autor, devem ser mencionados, pois são formas instigantes de compreender o processo de educação do corpo acionado pelo cronista. Um primeiro ponto a ser indicado é que os sports, em suas crônicas, serviam para definir a vida ociosa das elites cariocas, conforme apontam Imada e Levin (2020). A partir da associação com um verbo constantemente presente e com um significado próprio nas suas obras, o flanar5:

5 “'...] flanar, para João do Rio, é tão somente 'ter o vírus da observação ligado ao da vadiagem'. Vagar vadiamente é, sobretudo, perambular inutilmente, com espírito liberto, pois somente assim é possível deixar-se surpreender pelos objetos possíveis de admiração: 'nada como o inútil para ser artístico'. Nada na 'viagem' além de uma poética de observação" (CAMILOTTI, 2004, p. 152). Ou ainda: "Compreende-se, pois, que João do Rio identifique-se mais facilmente com sua segunda solução para o dilema do indivíduo: o flâneur. Cosmopolita desde o nome que o designa (flanar é definido por ele como um 'verbo universal', 'que não pertence a nenhuma língua'), o flâneur, assim como a palavra, 'não tem entrada nos dicionários', isto é, nas estruturas fixas da vida social. É um ser das passagens e da mobilidade, cuja atividade hesita entre definir-se como 'esporte' ou como 'arte', para a qual se requer 'espírito vagabundo, cheio de curiosidades malsãs e os nervos com um perpétuo desejo incompreensível” (VENEU, 1990, p. 9). 
Essas qualidades nós as conhecemos vagamente. Para compreender a psicologia da rua não basta gozar-lhe as delícias como se goza o calor do sol e o lirismo do luar. É preciso ter espírito vagabundo, cheio de curiosidades malsãs e os nervos com um perpétuo desejo incompreensível, é preciso ser aquele que chamamos flâneur e praticar o mais interessante dos esportes - a arte de flanar. É fatigante o exercício? Para os iniciados sempre foi grande regalo (BARRETO, 2002b, p. 5).

Um outro significado para o esporte encontrado em suas crônicas é aquele relacionado às ações de um indivíduo violento, principalmente dos jovens da elite carioca que viviam brigando. Nesse ponto, o termo se afasta da prática esportiva e é usado como um modo de vida que deveria ser eliminado da ambiência urbana, evidenciando que os seus textos tinham elementos civilizacionais:

Por que estão presos? José, por exemplo, deu com uma correia na mão de um filho do cabo de um delegado; Pedro e Joaquim, ao saírem do café onde estão empregados, discutiram um pouco mais alto; Antônio atirou uma tapona à cara de Jorge. Há na nossa sociedade moços valentes, cujo sport preferido é provocar desordens: diariamente, senhores respeitáveis atacam-se a sopapo; jornalistas velho-gênero ameaçam de vez em quando pelas gazetas, falando de chicote e de pau a propósito de problemas sociais ou estéticos, inteiramente opostos a esses aviltantes instrumentos de razão bárbara. Nem os moços valentes, nem os senhores respeitáveis, nem os jornalistas vão sequer à delegacia (BARRETO, 1951, p. 113).

Além de questionar a ociosidade e a violência, João do Rio utilizouse sutilmente do esporte para criticar a nova elite "endinheirada", servindo também para contextualizar a dinâmica social carioca das primeiras décadas do século XX, conforme evidenciado nas duas passagens abaixo, publicadas respectivamente nos anos 1911 e 1910 :

De resto, o negócio em elaboração não poderia ser senão um pequeno exercício sem método na sua vida a toda brida. A fatalidade naquele momento sobrecarregava-o de dois sports: o automóvel e a mulher. Tudo na vida é sport. O maior sportsman de todos os tempos foi positivamente Deus, Nosso Senhor. Esse cavalheiro, predestinado de fato, venceu todas as performances e todos os handicaps e, segundo observações inteligentes, 
foi o inventor do puzzle na organização do caos. Não é de admirar que a humanidade, à proporção que mais intimamente conhece Deus, mais esportiva se revele. A corrente contemporânea é particularmente esportiva. Os jornais falam de matches de velocidades. Os termos ingleses surgem a cada corrida ou a cada pontapé; as pessoas andam na rua como quem vem ou quem vai para um desafio ou pelo menos para uma aposta. Jacques, além da corrente pertencia a um grupo que tinha por chefe Jorge de Araújo. Comprou um reloginho para prender ao pulso e foi das velocidades (BARRETO, 2002a, p. 90).

E a viração era tão macia, um cheiro de salsugem polvilhava a atmosfera tão levemente, que a vontade era de ficar ali muito tempo, sem fazer nada. Mas a noite já estendia o seu negro brocado picado de estrelas e no pleinair do terraço começavam a chegar os smart-diners. Que curioso aspecto! Havia franceses condecorados, de gestos vulgares, ingleses de smoking e parasita à lapela, americanos de casaca e também de brim branco com sapatos de jogar o foot-ball e o lawn-tennis, os elegantes cariocas com risos artificiais, risos postiços, gestos a contragosto do corpo, todos bonecos vítimas da diversão chantecler, os noceurs habituais, e os michés ricos ou jogadores, cuja primeira refeição deve ser o jantar, e que apareciam de olheiras, a voz pastosa, pensando no bac chemin de fer; no 9 de cara e nos pedidos do último béguin (BARRETO, 1978, p. 1).

As passagens evidenciam que o linguajar tipicamente esportivo extrapolava a cenário de tais práticas. Essa retórica saia da esfera esportiva propriamente dita e invadia os recônditos da vida cotidiana. Nos trechos o cronista evidencia o caráter artificial de uma parte da elite carioca e novamente um discurso relacionado a uma educação do corpo foi acionado por João do Rio.

Outra faceta explorada pelo escritor em relação a palavra sport é o aspecto em que ele relaciona o termo como uma forma de tortura psicológica. Neste caso trata-se de um jovem militar proibido de se comunicar com os demais companheiros por ordem de seu comandante:

Era de tal modo grave a atitude do comandante que nenhum de nós se atreveu a interrogá-lo. Também a explicação veio minutos depois, terminante e terrível. O tenente João chamou-nos de parte e em voz seca deu a ordem de cima. O Sr. comandante proíbe que se converse ou se responda ao preso. O Sr. comandante considera uma deslealdade à causa e à sua pessoa dizer uma palavra ao Sr. Godard, até segunda ordem. Era o suplício do silêncio! Era o castigo! Alguns acharam fraco — eram os 
ingênuos. Outros sorriram, imaginando as resultantes daquele sport, a perseguição do silêncio ao pobre sujeito. Como tomaria ele a vingança? [...] E foi então a luta mais curiosa e mais atroz, o sport mais doloroso e mais inquietante que jamais viramos, entre a palavra e o silêncio. Cada um de nós, com o instinto animal de vencer, não respondia só para obedecer ao comandante, não respondia porque responder seria a vitória do pobre diabo. [...] De modo que no vaso de guerra em plena revolta, havia apenas o diabólico sport de um homem contra trezentos, querendo falar, querendo viver, querendo rebentar o sudário de silêncio com que o enterravam moralmente, sem o conseguir (BARRETO, 2000, p. 21-22).

Novamente a utilização do termo extrapolava o universo esportivo e atingia outras esferas do cotidiano. A passagem sinaliza em suas entrelinhas a relação que a palavra esporte tinha com o corpo, demonstrando que tanto em seu sentido lato, como no restrito, o termo exigia um enorme autocontrole do corpo pelo indivíduo, bem como um elemento de desafio.

O escritor também se utilizou do esporte para caracterizar a arte de flertar. Artimanha esta, estampada de forma artificial e ardilosa, por meio de uma relação de poder explícita entre um mancebo da fina-flor carioca e sua pretendente, uma jovem de família sem posses e ingênua:

Eu vou, eu passo, eu cumprimento. No dia seguinte torno a passar. Três dias depois, mando-lhe uma recordação. Tudo é tão simples com os pobres! Dentro em pouco a criaturinha sente-se envolvida numa atmosfera de cuidados e de delicadezas. A princípio é apenas a vaidade. Um homem tão bem vestido, tão distinto, tão fino, que podia ser amado por lindas mulheres da sua ordem... Depois o orgulho, a sensação de que é melhor do que as outras por ter sido a preferida, — orgulho que se perfuma de gratidão, uma vaga, muito vaga sensibilidade. Em seguida, a alegria da intimidade de um ente que não a ralha, que lhe reflete em admirações como um espelho simpático todas as pequenas belezas da sua beleza. Mas, ainda assim, não é amor, é brincadeira, uma brincadeira agradável, o namoro - o namoro que está para o flerte como a pureza de uma água pura para a falsificação de um vinho mau. Eu persisto, então, continuo, prolongo a grande cena. E de repente a criança sente o ciúme, um doce e ingênuo ciúme que tem zelos até do inanimado, anseia, treme, e ri e chora sem saber porque, toda ela possuída do perpétuo mal da vida. Então, eu sinto no intuito uma alegria infernal. É o meu esporte, o meu exercício, o meu prazer de homem da cidade. As regras são infalíveis como para todos os jogos, e a vitória sorri-me. Tenho satisfeito o meu desejo? (BARRETO, 2000, p. 59). 
Novamente o cronista associa o esporte como um modo de vida, porém, nesse trecho o escritor vai além, pois expõe comportamentos dissimétricos socialmente. Aqui o termo esporte e todo um linguajar esportivo é associado à técnica de sedução usada pelo jovem da elite carioca em relação às meninas pobres da cidade do Rio de Janeiro.

Como visto o esporte era frequentemente associado ao estilo de vida de uma parcela mais abastada da população, sempre em um tom sutilmente irônico. No caso abaixo, dando a entender que o bandido, frequentador do segmento elitista da cidade, sentia prazer no fato de cometer furtos de objetos de significativo valor:

E aquela frase dita tristemente preocupou-me. No fundo, porém, o sujo e ilustre homem tinha razão. O gatuno, ou o sportsman da ladroeira não era Antônio, era outro, existia, anunciava a sua presença, estava ali, ao nosso lado. Audácia? Loucura? Estupidez? No dia seguinte deu-se por falta do colar de ouro com pedras finas da atriz Simões, os brincos da mulher do tuberculoso sumiram-se. Foi o terror. Os hóspedes trancavam o quarto e saíam levando os valores no bolso, mesmo para almoçar. A limpeza era feita na presença dos respectivos locatários. Já ninguém se falava direito, já ninguém conversava. Havia entre nós um ladrão. Um ladrão! (BARRETO, 2000, p. 54-55).

O rol de sinônimos da palavra sport nos escritos de João do Rio demonstrava, sobretudo, um dos preceitos básicos do dandismo: causar controvérsias e contradições, pois em outras passagens, algumas nas mesmas obras, o esporte tinha outros significados, só que agora de índole positiva, evidenciando uma outra dimensão educacional. $\mathrm{O}$ fato é que, a medida em que o esporte passou a ganhar a simpatia de camadas mais populares, João do Rio passou a apresentá-lo em seus textos com uma fina e sutil ironia - um traço literário típico do autor (CANDIDO, 1992). De qualquer modo, a noção de sportman é reportada como uma importante referência de civilidade. Por exemplo, quando se utilizou da figura de Santos Dumont, célebre personagem do início do século XX no Brasil:

Há pelo menos duas tolices em tal moxinifada154. O music hall ficava, entretanto, apinhado de jovens soldados, de marinheiros, de mocinhos patriotas; e eu hei de lembrar sempre certa vez em que, passando pelo café-cantante, ouvi o barulho da apoteose e entrei. Estava o Dudu das 
Neves, suado, com a cara de piche a evidenciar trinta e dois dentes de uma alvura admirável, no meio do palco e em todas as outras dependências do teatro a turba aclamava. O negro já estava sem voz.

Assinalou para sempre o século vinte

O herói que assombrou o mundo inteiro

Mais alto que as nuvens, quase Deus

É Santos Dumont um brasileiro

E após essa rajada de hipérboles ao Dumont que todos nós conhecemos, sportman, elegante, acionista da Mogiana, bem homem da sua época, eu vi no estridor das aclamações Fausto Cardoso, poeta, político, patriota, agitar freneticamente um lenço, válido de emoção... Era a vitória da calçada, era a poesia alma de todos nós, era o sentimento que brota entre os paralelepípedos com a seiva e a vida da pátria (BARRETO, 1951, p. 90).

O engrandecimento de elementos ligados ao universo esportivo era mais nítido quando o cronista se reportava aos valores físicos e estéticos da cultura greco-romana, por sinal, algo bastante valorizado na produção de João do Rio:

- Rapazes, foi assim que os gregos venceram em Salamina! Depois disso, há dezesseis anos, o Rio compreende definitivamente a necessidade dos exercícios, e o entusiasmo pelo football, pelo tennis, por todos os outros jogos - sem diminuir o da natação e das regatas - é o único entusiasmo latente do carioca. Rendamos homenagem às Regatas do Flamengo. [...] O campo do Flamengo é enorme. Da arquibancada eu via o outro lado, o das gerais, apinhado e gente, a gritar, a mover-se, a sacudir os chapéus. Essa gente subia para a esquerda, pedreira acima, enegrecendo a rocha viva. Embaixo a mesma massa compacta. $\mathrm{E}$ a arquibancada, o lugar dos patrícios no circo romano, era uma colossal, formidável corbelha de belezas vivas, de meninas que pareciam querer atirar-se e gritavam o nome dos jogadores, de senhoras pálidas de entusiasmo, entre cavalheiros como tontos de perfume e também de entusiasmo (JOÃO DO RIO, 1917 apud RAMOS, 1990, p. 19-20).

A influência clássica era notória no período. Se os ideais higiênicos importados da Europa eram evidentes no meio intelectual brasileiro (GÓIS JÚNIOR; LOVISOLO, 2003), a tradição inventada que ligava as modernas práticas físicas (os movimentos ginásticos, a educação física e, sobretudo, os esportes) às diversas formas de movimento realizadas na cultura greco-romana eram uma constante. Era a difusão de um novo modelo estético-corporal que 
se materializou em obras de importantes intelectuais da esfera da Educação e da Educação Física, como Fernando de Azevedo (1920a, 1920b).

Além disso, como precursor do colunismo social e indivíduo integrado as coisas da sua cidade, Paulo Barreto mantinha um interesse no processo de reestruturação do espaço urbano e a ocupação e circulação de pessoas nos locais públicos. Nas palavras do cronista, havia a demonstração de que a partida, por si só, tinha uma importância menor do que o aspecto social que estava envolvido na prática esportiva:

[...] Os gritos, as exclamações destacavam-se mais na luz do ocaso, e de todos os lados subia o clamor da turba, um clamor de circo romano, um clamor de Hipódromo no tempo em que era basilissa Teodora, a maravilhosa... [...] O meu velho amigo dizia, quase desmaiado: Venceu o Flamengo num score de quatro a um... À porta quinhentos automóveis buzinavam, bufavam, sirenavam. E as duas portas do campo golfavam para a gente do Guanabara mais de seis mil pessoas arrasadas da emoção paroxismada do football (JOÃO DO RIO, 1917 apud RAMOS, 1990, p. 20-21).

Enfim, para o autor, "Tudo na vida é sport. Na vertigem da corrida nem sempre servem as performances..." (BARRETO, 2002a, p. 94), isto é, seguidor da máxima da cultura dândi da excepcionalidade, Paulo Barreto, provavelmente de modo inédito, deslocou o foco primário da prática em si para a assistência (o público). Assim, o esporte não tinha uma maior significância para Paulo Barreto. Para o literato era somente uma interessante aglomeração de pessoas e um bom tema cotidiano para as suas crônicas - espaço no qual manifestava também o seu pertencimento à cultura dândi. Sublimar a oscilação entre a adoração e a sátira ao esporte seria um equívoco, pois estar-se-ia "caindo" na própria "armadilha" literária criada pelo autor. Como dândi, era importante se posicionar de modo polêmico e (não raro) contraditório.

Seu parecer era, via de regra, aversivo ao convencional (um termo usado pelo próprio autor). Assim, o aspecto social manifesto nos seus textos era uma questão secundária, já que a sua crônica - também os escritos de outros gêneros, só que de maneira mais tênue - expressava a sua controversa individualidade, que, por sua vez, incorporava a uma tendência predominante na Europa - o dandismo (CAMILOTTI, 2004). Observe-se, por exemplo, esta manifestação direta em uma fonte de 1911, na qual é enfatizada a banalidade presente nos clubes esportivos: 
É incontestável que o automóvel dá muito dinheiro a ganhar. Principalmente a quem neles trabalha pouco, ou não trabalha mesmo nada. O automóvel faz ganhar em maior parte aos intermediários das vendas. Esses jovens vinham para as encomendas do governo, repartiam largamente as comissões e a atmosfera foi em certo momento tal que todos acordaram ser uma vergonha não haver ainda um automóvel-club. Se todos auto-mobilizavam, se todos eram loucos pelo sport, por que não haver um club? E de um momento para outro, o club surgiu mesmo na praia, em frente à Beira-Mar, ocupando um velho prédio familiar. Jacques frequentava-o, sem aliás lhe encontrar encantos. $\mathrm{O}$ club, montado à pressa, tinha como mobiliário mesas repletas de revistas esportivas que ninguém lia, pelas paredes algumas caricaturas inglesas e francesas tratando de cavalos, de pólo, d'automóveis, de cricket e de lawn tennis e umas vagas poltronas, de um modernismo que nem ao Mapple pedia auxílio. À porta era toda noite um carbuncular de faróis de autos e a algazarra da penúltima profissão inventada pela civilização: os chauffeurs que os sportsmen tratavam como antes dos chauffeurs só era possível tratar o seu cavalo ou a sua cocotte. A diretoria, enquanto não se dissolvia o club, falava seriamente nas possibilidades de um circuito (BARRETO, 2002a, p. 90).

Muitas vezes as sátiras e ironias de João do Rio, de tão sutis, poderiam ser confundidas com os desvelados elogios dos literatos admiradores do esporte, como Bilac, Coelho Netto e Gilberto Amado. É fato, então, que contava com o conhecimento prévio do seu leitor. A crônica, por manter uma regularidade de publicação, favorece que o seu leitor conheça melhor a personalidade - ao menos a literária - do autor. Um exemplo de sutil ironia segue abaixo:

[...] A sede do club estava a dois passos da casa de Júlio Furtado, que protetoramente amparava o delírio muscular da rapaziada. As pessoas graves olhavam "aquilo" a princípio com susto. O povo encheu-se de simpatia. E os rapazes passavam de calção e camisa-de-meia dentro do mar a manhã inteira e a noite inteira [...] pela cidade, jovens, outrora raquíticos e balofos, ostentavam largos peitorais e a cinta fina e a perna nervosa e a musculatura herculana dos braços. Era o delírio do rowing, era a paixão dos sports. Os dias de regatas tornavam-se acontecimentos urbanos (JOÃO DO RIO, 1917 apud RAMOS, 1990, p. 18-19). 
Nota-se que, provavelmente, não se tratava de um elogio à condição física saudável que o esporte proporcionava a juventude brasileira, mas sim, uma implícita ironia elogiosa aos corpos dos atletas. Sabendo-se, conforme indica Green (2000), que Barreto tinha uma sexualidade ambígua e que, dentro dos limites sociais da sua própria época ${ }^{6}$, não fazia muita questão de esconder suas preferências, percebe-se, principalmente para aqueles leitores que disto sabiam, que a descrição dos atletas tinha um outro significado. Quem sabe até, sem sair do plano hipotético, Paulo Barreto satirizasse também aqueles literatos que incessantemente louvavam a cultura atlética, questionando a própria sexualidade destes.

Porém, mesmo sendo simpatizante da cultura dândi, Paulo Barreto não ultrapassaria os limites da sutileza. Não tinha fortes querelas como outros literatos, a exceção era Humberto de Campos. Ao contrário, tinha um relacionamento amistoso com o meio intelectual, inclusive seu reconhecimento como literato se deu após a publicação em 1905 da obra "O Momento Literário", na qual fez um misto de biografia e crítica literária (bastante elogiosa) a vários escritores brasileiros de destaque, a partir de entrevistas realizadas pessoalmente ou via correspondência (BARRETO, 2002b). Entre os autores contemplados na sua obra, destacavam-se: Olavo Bilac, João Ribeiro, Sílvio Romero, Coelho Netto, Lima Campos, Mario Pederneiras, Luís Edmundo, Clóvis Beviláqua, Artur Orlando, Silva Ramos, Rodrigo Otávio, Inglês de Souza, Rocha Pombo, Elísio de Carvalho, Raimundo Correia. Além de outros que foram pleiteados por Paulo Barreto, mas declinaram ou não responderam ao convite: Machado de Assis, Graça Aranha, Aluísio Azevedo, Artur Azevedo, Alberto de Oliveira, Emílio de Menezes e José Veríssimo.

6 Novamente um ponto em comum entre Paulo Barreto e Oscar Wilde, um dos literatos que mais influenciaram o cronista brasileiro, a sexualidade. Paulo Barreto chegou a ser satirizado por Lima Barreto por meio de um personagem homossexual na obra "Recordações do Escrivão Isaias Caminha". 


\section{Conclusões}

A controversa cultura dândi de João do Rio tinha um limite: a ofensa. Como não era de se indispor, consequentemente não tendo desafetos de peso no meio literário, ganhara a simpatia da maioria dos autores que biografou em seu livro. Logo, a sua candidatura a uma das cadeiras da Academia Brasileira de Letras foi aceita sem maiores polêmicas (VENEU, 1990). Mesmo tendo seguido um estilo de forte valor estético, centrado em uma posição de contrariar, o literato deixava bem claro ao produzir seus textos que existia um tênue limite entre aquilo que poderia ser contrariado sem indisposições e o que geraria polêmicas exageradas.

Mesmo sendo um crítico do modo de vida das elites, João do Rio era um dos escritores mais integrados ao seu mundo. Pode ser considerado um exímio conhecedor da mentalidade da sua época, pois conseguia, na maioria das vezes, se manifestar contrário à opinião geral, sem ultrapassar o limite que o levaria a criar antipatias, tanto entre os seus pares quanto entre o seu público leitor. Então, no caso dos esportes, o seu posicionamento, mesmo que simpático à prática (no início), ficava bem aquém de outros literatos, como Coelho Netto, por exemplo. Quando o esporte se popularizou, aí João do Rio passou a demonstrar certo cansaço da sua presença, porém, sempre naquele limite que evitava querelas exacerbadas.

Contudo, suas crônicas relativas ao termo sport estavam em sintonia com o sentimento de "missão civilizacional", levantado por Sevcenko (1983), já que, ao explorar a vida mundana da sociedade carioca, João do Rio acionava diversos elementos educativos. Afinal, os comportamentos e hábitos da sociedade ao serem ora questionados ora valorizados idealizavam imagens que os leitores buscavam aplicar na ambiência urbana do período, estando dentro dos elementos da "comunidade imaginada" preconizada por Anderson (2008). Nesse sentido, pode-se afirmar que uma educação do corpo era algo significativamente presente na obra de João do Rio. 


\section{REFERÊNCIAS}

ANDERSON, Benedict. Comunidades imaginadas: reflexões sobre a origem e a difusão do nacionalismo. São Paulo: Companhia das Letras, 2008.

ARNT, Héris. A influência da literatura no jornalismo: o folhetim e a crônica. Rio de Janeiro: E-papers, 2001.

AZEVEDO, Fernando de. Da educação physica. São Paulo: Weiszflog Irmãos, 1920a.

AZEVEDO, Fernando de. Antinoüs: estudo de cultura atlhetica. São Paulo: Weiszflog Irmãos, 1920 b.

BARRETO, Paulo (João do Rio). Cinematographo (crônicas cariocas). Porto: Livraria Chardon, 1909.

BARRETO, Paulo (João do Rio). A alma encantadora das ruas. Rio de Janeiro: Organizações Simões, 1951.

BARRETO, Paulo (João do Rio). Dentro da noite. Rio de Janeiro: Inelivro, 1978.

BARRETO, Paulo (João do Rio). Dentro da Noite. Pará de Minas: Virtualbooks, 2000.

BARRETO, Paulo (João do Rio). A profissão de Jacques Pedreira. Pará de Minas: Virtualbooks, 2002a.

BARRETO, Paulo (João do Rio). O momento literário (conferência). Pará de Minas: Virtualbooks, 2002b.

CAMILOTTI, Virginia Celia. João do Rio: ideias sem lugar. 2004. Tese (Doutorado em História) - Instituto de Filosofia e Ciências Humanas, Universidade de Campinas, Campinas, 2004.

CANDIDO, Antônio et al. A Crônica. Campinas: Editora da Unicamp, 1992.

CANDIDO, Antônio. Literatura e Sociedade: estudos de teoria e história literária. São Paulo: Queiroz, 2000.

CAPRARO, André Mendes. História de matches e de intrigadas da sociedade: a crônica literária e o esporte futebol. São Paulo: Annablume, 2013.

CAPUANO, Claudio de Sá. O dândi e a modernidade: aspectos da ficção de João do Rio. Palimpsesto, Rio de Janeiro, v. 1, n. 1, p. 11-30, 1999.

ECO, Umberto. Sobre a Literatura. Rio de Janeiro: Record, 2003.

ECO, Umberto. História da Beleza. Rio de Janeiro: Record, 2004.

GÓIS JUNIOR, Edivaldo; LOVISOLO, Hugo Rodolfo. Descontinuidades e continuidades do movimento higienista no Brasil do século XX. Revista Brasileira de Ciências do Esporte, Campinas, v. 25, n. 1, p. 41-54, 2003. 
GOMES, Renato Cordeiro. João do Rio: vielas do vício, ruas da graça. Rio de Janeiro: Relume Dumará, 1996.

GONÇALVES, Márcia Rodrigues. O Rio de Janeiro de Coelho Neto - do império à república. 2016. Tese (Doutorado em Literatura portuguesa e luso-africana) Universidade Federal do Rio Grande do Sul, Porto Alegre, 2016.

GREEN, James N. Além do Carnaval: a homossexualidade brasileira no Brasil do século XX. São Paulo: UNESP, 2000.

IMADA, Heloísa Leite; LEVIN, Orna Messer. Vestida para o lazer: a descrições da moda nas crônicas mundanas de João do Rio. ModaPalavra e-periódico, Florianópolis, v. 13, n. 29, p. 70-103, 2020.

LEVIN, Orna Messer. As figurações do dândi: um estudo sobre a obra de João do Rio. Campinas:Editora da Unicamp, 1996.

LUCENA, Ricardo Figueiredo. O esporte na cidade: aspectos do esforço civilizador brasileiro. Campinas: Autores Associados, 2001.

MELO, Victor Andrade. Cidade sportiva: primórdios do esporte no Rio de Janeiro. Rio de Janeiro: Relume Dumará, 2000.

MICELI, Sérgio. Poder, Sexo e Letras na República Velha. São Paulo: Perspectivas, 1977.

MORENO, Andrea. Corpo e práticas corporais nas crônicas de Machado de Assis. Revista Brasileira de Ciência do Esporte, Brasília, v. 1, p. 1293-1294, 1999.

O’DONNELL, Julia. De olho na rua: a cidade de João do Rio. São Paulo: Companhia das Letras, 2008.

CHAlHOUB, Sidney; PEREIRA, Leonardo Affonso de Miranda (org.). A História Contada. Capítulos de História Social da Literatura Brasileira. Rio de Janeiro: Nova Fronteira, 1998.

RAMOS, Ricardo. A Palavra É... Futebol. São Paulo: Scipione, 1990.

RODRIGUES, João Carlos. João do Rio: uma biografia. Rio de Janeiro: Topbooks, 1996.

SEVCENKO, Nicolau. Literatura como missão: tensões sociais e criação cultural na Primeira República. São Paulo: Brasiliense, 1983.

SEVCENKO, Nicolau (org.). História da vida privada no Brasil. São Paulo: Cia das Letras, 1998. v. 2.

SOARES, Carmen Lúcia. Apresentação do dossiê: A visibilidade do corpo. Pró-Posições, Campinas, v. 14, n. 2, p. 15-19, 2003.

SOARES, Carmen Lúcia. Educação do corpo (verbete). In: GONZÁLEZ, Fernando Jaime; FENSTERSEIFER, Paulo Evaldo (org.). Dicionário crítico de Educação Física. Ijuí: Unijuí, 2014. p. 219-225. 
VENEU, Marcos Guedes O Flâneur e a Vertigem. Metrópole e subjetividade na obra de João do Rio. Revista Estudos Históricos, Rio de Janeiro, v. 3, n. 6, p. 229-243, 1990.

VIGARELLO, Georges; HOLT, Richard. O corpo trabalhado - Ginastas e esportistas no século XIX. In: CORBIN, Alan; COURTINE, Jean-Jacques; VIGARELLO, Georges (org.). História do Corpo: da revolução à grande guerra. Petrópolis, RJ: Vozes, 2008. p. 445-480.

WEGUELIN, João Marcos. O Rio de Janeiro através dos jornais. UOL o melhor conteúdo [online]. [S.l.], [20--]. Disponível em: https://www1.uol.com.br/rionosjornais/rj27.htm. Acesso em: 21 mar. 2021.

WILDE, Oscar. O retrato de Dorian Gray. Porto Alegre: L\&PM, 2001.

Texto recebido em 01/10/2020.

Texto aprovado em 27/01/2021. 